\section{(2) OPEN ACCESS}

\title{
Takotsubo cardiomyopathy triggered by SARS-CoV-2 infection in a critically ill patient
}

\author{
Fadi Taza, Mary Zulty, Arjun Kanwal (D) , Daniel Grove
}

Internal Medicine, MedStar Union Memorial Hospital, Baltimore, Maryland, USA

\section{Correspondence to} Dr Arjun Kanwal; arjun.kanwal@medstar.net

Accepted 31 May 2020
Check for updates

(c) BMJ Publishing Group Limited 2020. Re-use permitted under CC BY-NC. No commercial re-use. See rights and permissions. Published by BMJ.

To cite: Taza F, Zulty M, Kanwal A, et al. BMJ Case Rep 2020;13:e236561. doi:10.1136/bcr-2020236561

\section{SUMMARY}

COVID-19 became a global pandemic in early 2020 . While well known for its pulmonary manifestations, the virus also has a number of cardiac manifestations as well. Takotsubo syndrome has scarcely been reported in patients with COVID-19, but it is possible that the cytokine storm associated with the infection can trigger Takotsubo syndrome in patients with underlying risk factors for Takotsubo (emotional distress, physical distress, history of psychiatric disorders).

\section{BACKGROUND}

COVID-19, also known as severe acute respiratory syndrome coronavirus 2 (SARS-CoV-2), which originated in China in late 2019, has spread rapidly resulting in a global pandemic. The cardiovascular complications remain under investigation. Here, we present a case of Takotsubo syndrome in a patient with COVID-19 infection.

\section{CASE PRESENTATION}

\section{History of present illness}

A 52-year-old man presented to the emergency department with shortness of breath. He was altered, febrile, tachypneic and hypoxic. Lung auscultation revealed bibasilar crackles and cardiac examination was normal. Laboratory tests were significant for an elevated C-reactive protein $(276 \mathrm{mg} / \mathrm{L})$, elevated $\mathrm{D}$-dimer $(3.45 \mu \mathrm{g} / \mathrm{mL})$ and normal troponin I $(<0.015 \mathrm{ng} / \mathrm{mL})$. In the emergency room, he underwent endotracheal intubation due to acute hypoxic respiratory failure and altered mental status, and admitted to the intensive care unit. On the evening of hospital day 2 , he became haemodynamically unstable and noted to have ST segment elevations on the telemonitor.

\section{Medical history}

The patient is a nursing home resident with history of schizophrenia, diabetes mellitus and hypertension. He was recently diagnosed with SARS-CoV-2 by reverse transcription PCR of a nasopharyngeal swab at his nursing home.

\section{INVESTIGATIONS}

ECG revealed ST segment elevations in the inferior leads (II, III, aVF; figure 1). Laboratory testing demonstrated normal levels of cardiac troponin I $(<0.015 \mathrm{ng} / \mathrm{L}$; reference range $(\mathrm{RR})$ $<0.045 \mathrm{ng} / \mathrm{L}$ ). He underwent emergent coronary angiography due to haemodynamic instability, which revealed non-obstructive coronary arteries (figure 2) and apical ballooning on ventriculography (figures 3 and 4), consistent with Takotsubo syndrome. The estimated left ventricular (LV) ejection fraction was $45 \%$.

\section{DIFFERENTIAL DIAGNOSIS}

The differential diagnosis includes acute inferior wall infarction, pericarditis, myocarditis, vasospasm (Prinzmetal's syndrome) and Takotsubo syndrome.

Based on the ECG changes, acute myocardial infarction was possible. The patient had ST elevations in II, III, aVF, signalling a right coronary artery infarct. Pericarditis was possible, however, less likely given the distributional pattern of ST segment elevations, rather than a diffuse pattern. The patient never had cardiac MRI; however, myocarditis was unlikely given ventriculogram findings and negative troponin. The most likely diagnosis remains Takotsubo syndrome based on the patients apical ballooning on ventriculogram and patent coronary arteries on angiography.

\section{TREATMENT}

Treatment was started with colchicine and methylprednisolone $1 / \mathrm{mg} / \mathrm{kg} /$ day given elevated serum inflammatory markers: C-reactive protein $(217 \mathrm{mg} / \mathrm{L} ; \mathrm{RR}<3 \mathrm{mg} / \mathrm{L})$, ferritin $(1427 \mathrm{ng} / \mathrm{mL}$; RR $28-365 \mathrm{ng} / \mathrm{mL}$ ), erythrocyte sedimentation rate $(84 \mathrm{~mm} /$ hour; RR $0-20)$ and interleukin-6 (IL-6; $67 \mathrm{pg} / \mathrm{mL} ; \mathrm{RR} \leq 5 \mathrm{pg} / \mathrm{mL}$ ). He was also started on intravenous continuous heparin infusion for anticoagulation in the setting of his elevated D-dimer $(2.40 \mu \mathrm{g} / \mathrm{mL} ; \mathrm{RR} \leq 0.52)$ and concern for SARS-CoV-2-induced thrombophilia. On day 2, tocilizumab was administered for IL-6 inhibition based on evidence of a hyperinflammatory state and likely cytokine storm. He clinically improved and on hospital day 6 , he was extubated and downgraded to a medical floor.

\section{OUTCOME AND FOLLOW-UP}

He clinically improved and on hospital day 6, he underwent endotracheal extubation and downgraded to a medical floor. The patient finished 3 days of methylprednisolone $(40 \mathrm{mg}$ two times per day) and remains on intravenous continuous heparin infusion for anticoagulation. His oxygen requirements decreased to $2 \mathrm{~L} / \mathrm{min}$ of nasal canula with oxygen saturations between $95 \%$ and $98 \%$. 


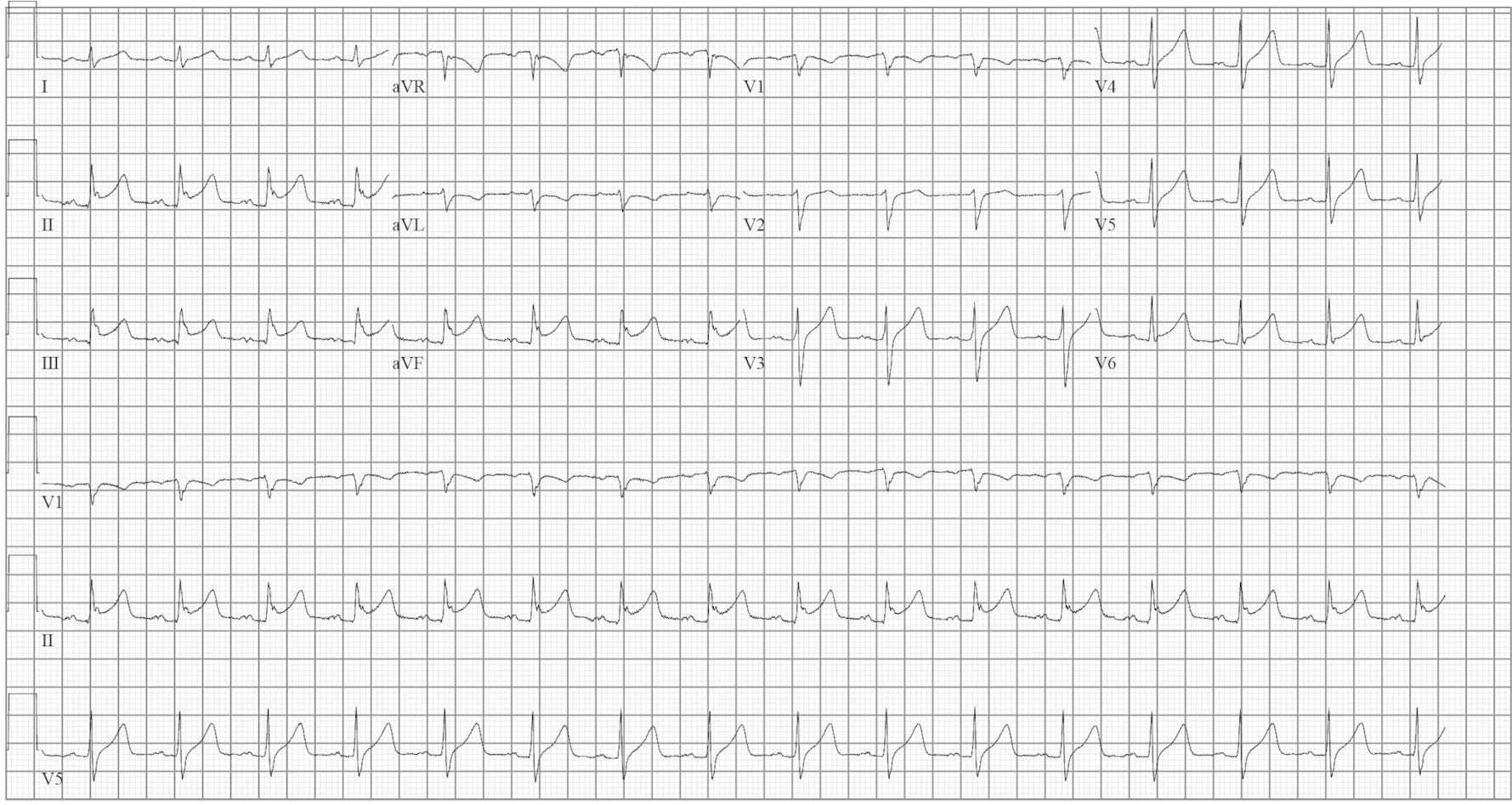

Figure 1 ECG with ST segment elevations in leads II, III and aVF, suggesting inferior wall myocardial infarction.

He was eventually discharged to outpatient rehabilitation without medical symptoms.

\section{DISCUSSION}

COVID-19, also known as SARS-CoV-2, ${ }^{1}$ which originated in Wuhan, China in late 2019, has spread rapidly resulting in a global pandemic. The cardiovascular manifestations and

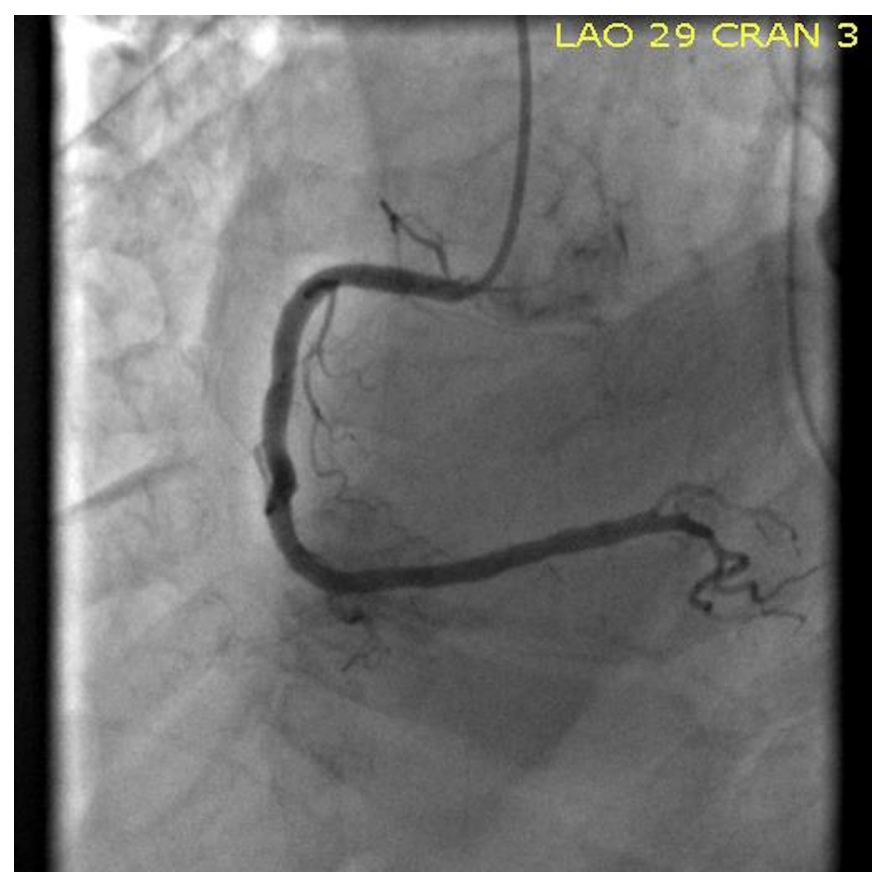

Figure 2 Coronary angiogram in left anterior oblique view demonstrating patent right coronary artery. clinical outcomes of patients with COVID-19 who develop myocardial injury during hospitalisation remain under investigation. Here, we report a case of a patient who developed Takotsubo syndrome in the setting SARS-CoV-2 infection. There were no signs of cardiac injury or myocardial involvement on presentation as demonstrated by normal ECG and absence of troponin I elevation.

Takotsubo syndrome or stress cardiomyopathy is a syndrome characterised by transient regional systolic dysfunction of the LV and ECG changes that mimic acute myocardial infarction in the absence of angiographic evidence of obstructive coronary

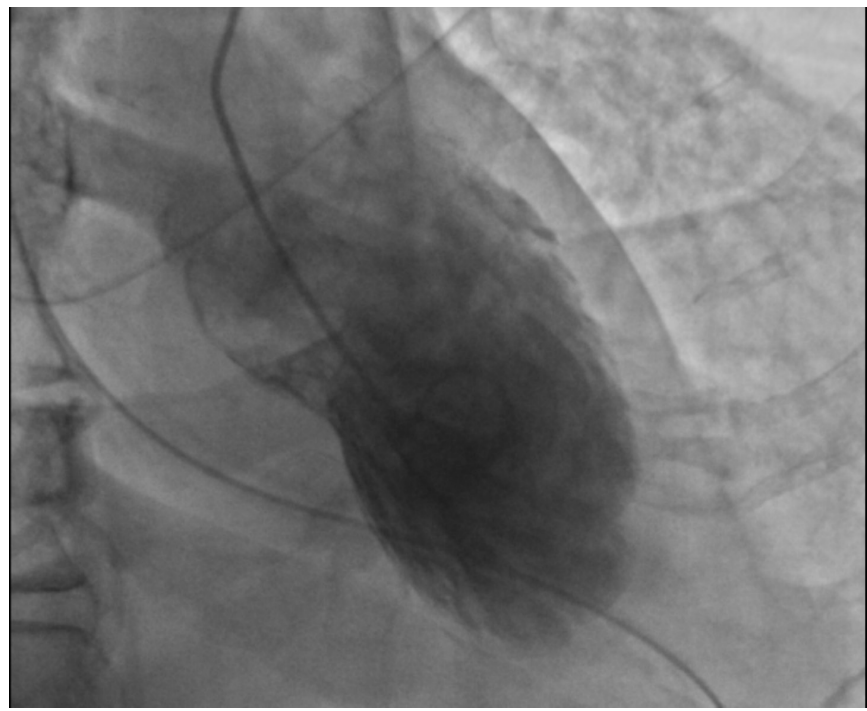

Figure 3 Ventriculogram during left heart catheterisation with normal diastolic filling. 


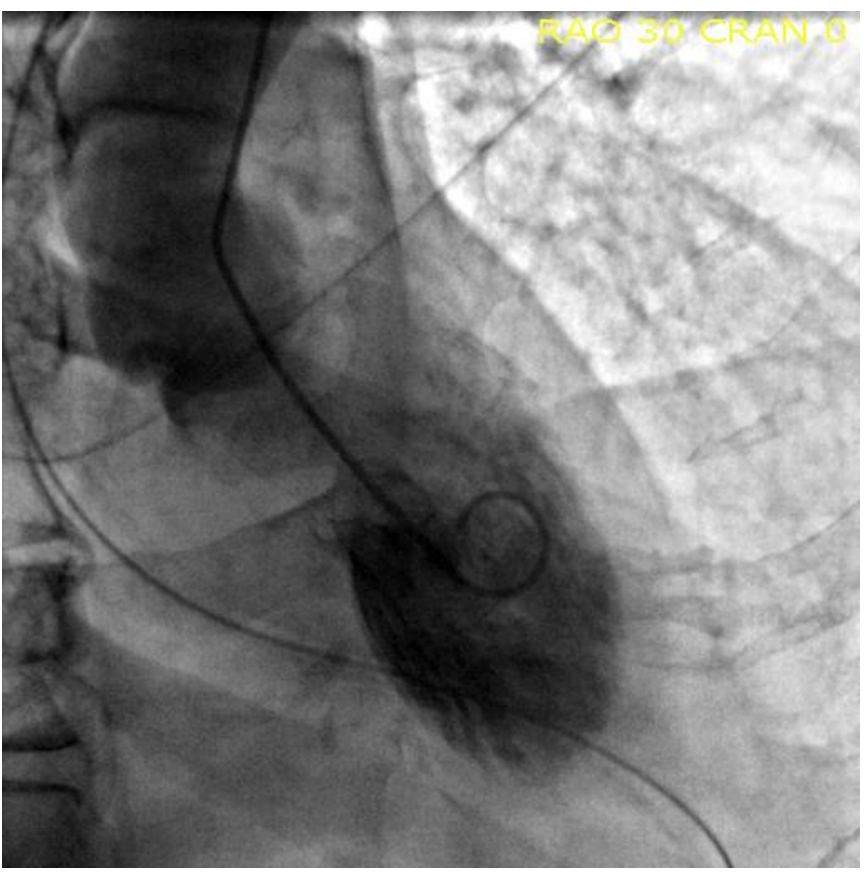

Figure 4 Ventriculogram during left heart catheterisation showing apical ballooning consistent with Takotsubo syndrome.

artery disease or acute plaque rupture. ${ }^{2}$ There are limited data regarding precipitating factors and the pathogenesis is not well understood. Rates of neurological and psychiatric disorders were higher in patients with Takotsubo syndrome compared with patients with acute myocardial infarction in the International Takotsubo Registry Study. ${ }^{3}$ Acute respiratory failure was found to be the most common physical trigger. ${ }^{3}$ Bacterial sepsis was reported to be the most frequent cause of Takotsubo syndrome; cases of Takotsubo syndrome attributed to viral infections are rare. ${ }^{4}$ Some studies have shown an elevation in catecholamine plasma levels suggesting this disorder may be caused by diffuse catecholamine-induced microvascular spasms or direct catecholamine-mediated myocyte injury. ${ }^{5}$ It is hypothesised that SARS-CoV-2 elicits an exuberant systemic immune response with a cytokine release syndrome (CRS) characterised by elevated inflammatory markers. ${ }^{67}$ The presence of a surge of catecholamine levels has been reported by Staedtke $e t a l^{8}$; however, the details of this response are not fully explained. Our patient met the diagnostic criteria for Takotsubo syndrome as evident by ECG findings, normal troponin I levels, non-obstructive coronary angiogram, apical ballooning on ventriculography and absence of pheochromocytoma or myocarditis. ${ }^{9}$ Echocardiogram could have been useful in the diagnosis of Takotsubo syndrome in our patient; however, it was not performed. Similarly, cardiac MRI would have definitively ruled out myocarditis; however, it was not performed as the patient improved and to minimise the spread of the virus by avoiding non-essential testing. Pericarditis was unlikely given normal troponin I levels and the absence of diffuse ST segment elevations on ECG. Acute coronary syndrome was ruled out as coronary angiography showed patent coronary arteries. To date, only two case reports in the literature have reported, a case of COVID-19 infection complicated by Takotsubo syndrome. ${ }^{10} 11$ We hypothesise that CRS triggered by COVID-19 with a subsequent rise in catecholamines may play a role in the pathogenesis of Takotsubo syndrome in patients with COVID-19 infections.

\section{Learning points}

- COVID-19 remains an ongoing global health emergency with varied clinical manifestations besides primary pulmonary symptoms.

- Caregivers must remain vigilant towards cardiac manifestations of COVID-19 syndrome as these could be potentially serious and life threatening.

- Cytokine storm induced by COVID-19 infection may play a significant role in stress cardiomyopathy.

Twitter Fadi Taza @faditaza and Arjun Kanwal @arjun.kanwal

Contributors All authors contributed to this manuscript. FT was responsible for creation of manuscript. AK was responsible for consent and editing of manuscript. $\mathrm{MZ}$ was responsible for writing and editing manuscript. DG was responsible for editing manuscript and retrieving images.

Funding The authors have not declared a specific grant for this research from any funding agency in the public, commercial or not-for-profit sectors.

Competing interests None declared.

\section{Patient consent for publication Obtained}

Provenance and peer review Not commissioned; externally peer reviewed.

Open access This is an open access article distributed in accordance with the Creative Commons Attribution Non Commercial (CC BY-NC 4.0) license, which permits others to distribute, remix, adapt, build upon this work non-commercially, and license their derivative works on different terms, provided the original work is properly cited and the use is non-commercial. See: http://creativecommons.org/ licenses/by-nc/4.0/.

\section{ORCID iD}

Arjun Kanwal http://orcid.org/0000-0002-6370-289X

\section{REFERENCES}

1 WHO. Naming the coronavirus disease (COVID-19) and the virus that causes it. World Health Organization, 2020.

2 Bybee KA, Kara T, Prasad A, et al. Systematic review: transient left ventricular apical ballooning: a syndrome that mimics ST-segment elevation myocardial infarction. Ann Intern Med 2004;141:858.

3 Templin C, Ghadri JR, Diekmann J, et al. Clinical features and outcomes of takotsubo (stress) cardiomyopathy. N Engl J Med.

4 Cappelletti S, Ciallella C, Aromatario M, et al. Takotsubo cardiomyopathy and sepsis. Angiology 2017;68:288-303.

5 Gianni M, Dentali F, Grandi AM, et al. Apical ballooning syndrome or takotsubo cardiomyopathy: a systematic review. Eur. Heart J 2006.

6 Huang C, Wang Y, Li X, et al. Clinical features of patients infected with 2019 novel coronavirus in Wuhan, China. Lancet.

7 Mehta P, McAuley DF, Brown M, et al. COVID-19: consider cytokine storm syndromes and immunosuppression. Lancet 2020;395:1033-4.

8 Staedtke V, Bai R-Y, Kim K, et al. Disruption of a self-amplifying catecholamine loop reduces cytokine release syndrome. Nature 2018;564:273-7.

9 Scantlebury DC, Prasad A. Diagnosis of takotsubo cardiomyopathy. Circ J 2014.

10 Meyer P, Degrauwe S, Van DC, et al. Typical takotsubo syndrome triggered by SARSCoV-2 infection. Eur Heart J.

11 Roca E, Lombardi C, Campana M, et al. Takotsubo syndrome associated with COVID-19. Eur J Case Rep Intern Med 2020:7:1665. 
Copyright 2020 BMJ Publishing Group. All rights reserved. For permission to reuse any of this content visit https://www.bmj.com/company/products-services/rights-and-licensing/permissions/

BMJ Case Report Fellows may re-use this article for personal use and teaching without any further permission.

Become a Fellow of BMJ Case Reports today and you can:

- Submit as many cases as you like

Enjoy fast sympathetic peer review and rapid publication of accepted articles

Access all the published articles

Re-use any of the published material for personal use and teaching without further permission

Customer Service

If you have any further queries about your subscription, please contact our customer services team on +44 (0) 2071111105 or via email at support@bmj.com.

Visit casereports.bmj.com for more articles like this and to become a Fellow 